\title{
The problem of water resources in central Asian countries
}

\begin{abstract}
In the article, the authors analyzed the current state of water use in Central Asian countries, identified the main problems of water use in this region. The concepts of improving the further rational use of water resources have been developed with the introduction of digital technologies.
\end{abstract}

Keywords: water, platinum, water resources, climate, Kambarata hydroelectric station, Sardoba reservoir
Volume 4 Issue 5 - 2020

\author{
Abdurakhmanov Kalandar Khodjaevich, \\ Dodoboev Yusubjon Tajibaevich, Khamidov \\ Bakhodirjon Sadikjanovich \\ 'Academician, Academy of Sciences of the Republic of \\ Uzbekistan, Doctor of Economics, Russia \\ ${ }^{2}$ Doctor of Economics, Russia \\ ${ }^{3}$ Applicant, Russia
}

Correspondence: Dodoboev Yusubjon Tajibaevich, Doctor of Economics, Russia, Email dodoboev4@mail.ru

Received: May 25, 2020 | Published: September 07, 2020

\section{Introduction}

The end of the twentieth - the beginning of the twentieth centuries was marked by the crisis of water resources and the consequences associated with it. In 1992, an international conference was held in Dublin, at which four Dublin crises were worked out:

a. Freshwater is a limited and vulnerable resource necessary to preserve life, development and the environment.

b. The development and management of water resources should be based on the joint efforts of users, developers of plans and policies at all levels.

c. Women play a major role in water supply, water management and protection.

d. Water is of great value to the economy in all its fields and should be recognized as an economic good.

On the same issue, in 1992 the UN developed the "Agenda 21", continued the process of the Second World Water Forum in 2000 in The Hague and the International Conference on Freshwater Resources in 2001 in Bonn. The most important was the 2000 UN Summit, which adopted the resolution "International Year of Freshwater, 2003" at the proposal of the President of the Republic of Tajikistan E. Rahmon. According to the initiator of the document, constructive planetary cooperation in solving the problem of the distribution of water resources is the most worthy solution to this problem and a guarantee that it will never have a military aspect. ${ }^{1,2}$

Water resources are renewable, therefore, it is not so much about saving them, but about their even distribution between economic sectors and states. Almost $70 \%$ of water resources are used in agriculture for irrigation, and in countries with a dry climate - almost $90 \%$. Experts believe that there are two ways to equalize the deficit due to the interstate distribution of resources:
I. Joint use of transboundary water reserves.
II. Trade in real or virtual water resources.

But in many cases, political interests impede this process. So, at the beginning of the 21 st century, more than 50 million people live in the Aral basin. This includes northern Afghanistan, southern and western Kazakhstan, whole Tajikistan and Kyrgyzstan. The Ferghana Valley stands out especially, where per 1sq. km. km 500-600 people live, and the area of irrigated agriculture is huge. Moreover, only two republics - Tajikistan and Kyrgyzstan - sources of water resources, other consumers. In the first, $55.4 \%$ of the flow of the Aral Sea basin is formed. Over the past decades, the Pamir mountains have reduced the amount of water reserves by half. Irrigation areas in the Aral basin have increased as much over the $20^{\text {th }}$ century, while in the world by 8times. Freshwater resources are the national wealth of Kyrgyzstan. In the country's glaciers, they are estimated at 650 billion cubic metres. Of the emerging runoff, the republic itself consumes only $20 \%$ of its percent, the rest is the neighbouring states of Central Asia. ${ }^{3}$

The Kyrgyz Toktogul hydropower hub is important for all Central Asian states. With its help, the national economy of the region, especially the Ferghana Valley, developed. Until 1991, Kyrgyzstan in the autumn-winter period received gas, coal, and fuel oil as compensation for the electricity generated by the hydroelectric power station. After the collapse of the USSR, republics sell Kyrgyzstan resources for dollars at a market price. And for a decade, they did not pay for the water received. Back in the Soviet period, the construction of the Kambarata hydroelectric station was laid in Kyrgyzstan, at the beginning of the century $30 \%$ of the work was completed. The government has repeatedly asked for help in this matter, but things are still there. In Uzbekistan, according to doctors, $80 \%$ of the causes of morbidity are poor water. The population of the republic is growing rapidly, and drinking water is becoming the most consumed resource. This can lead to conflicts due to its distribution. However, there is another opinion. Oregon American scientists have published evidence that water wars are a myth. The latter happened 4,5thousand years ago between the Mesopotamian cities - the states of Lagash and Ummah. ${ }^{4}$

In 1992, in Almaty, an agreement was signed between the five Central Asian republics on cooperation in the field of joint management of the use and protection of all water resources in the region. The use 
of water resources in Central Asia should be considered in accordance with generally recognized norms of international law, guaranteeing a rational and equitable distribution of water resources and ensuring that the interests of all states in the region are taken into account. In Central Asia, in connection with the arid climate, water problems are especially acute and transboundary water cooperation for many years left much to be desired. But in recent years, the situation has changed dramatically.

Transboundary water cooperation in Central Asia is carried out both on the basis of bilateral and multilateral formats. Recognizing the importance of maintaining Central Asia as a common region, Uzbekistan has stepped up efforts to promote water cooperation with neighbouring countries. Intergovernmental working groups have been established between Uzbekistan and other Central Asian countries on cooperation in the management of water resources on a bilateral basis. Uzbekistan supports draft conventions on the use of water resources of the Amu Darya and Syr Darya river basins developed by the UN Regional Center for Preventive Diplomacy. The adoption on June 22, 2018 of a special resolution of the UN General Assembly on Central Asia was a historic event. The resolution noted the importance of developing and strengthening bilateral and regional cooperation in the field of rational and integrated use of water energy resources in Central Asia, taking into account the interests of all states in the region.

Created 25years ago by the heads of state of Central Asia, the International Fund for Saving the Aral Sea (IFSAS) remains the only regional structure for water use and sustainable development. In 2018, he was granted observer status in the work of the UN General Assembly. Over the past quarter century, IFSAS has implemented three programs to assist countries in the Aral Sea basin. The Fund managed to draw the attention of the UN to the problem of the Aral Sea, the solution of water and environmental problems of Central Asia. Today, Uzbekistan is implementing major programs to improve the environmental and socio-economic situation in the Aral Sea region. Within the framework of the Comprehensive Program of Measures to Mitigate the Consequences of the Ural Disaster, Restore and Social and Economic Development of the Aral Sea Region for 2015-2018 235 projects completed. In addition, the State Program for the development of the Aral Sea region for 2017-2021 provide for the implementation of 67 projects and activities to mitigate the consequences of the Aral Sea disaster. For its implementation, the government created a development fund for the Aral Sea region.

The President of the Republic of Uzbekistan Shavkat Mirziyoyev said that the flood was a bitter lesson for us at a video conference on May 5, 2020, he separately focused on the work carried out in the Republic of Uzbekistan to combat coronavirus infection, as well as emergencies in the Bukhara and Syrdarya regions. The head of state noted in particular:

"We all see and observe how humanity is fighting both the coronavirus and the economic crisis."

A growing number of countries are gradually softening quarantine measures to overcome the difficult situation.

Today the epidemiological situation in Uzbekistan is stabilizing. With each passing day, the number of cured patients are becoming more than the sick. As well as people leaving quarantine than those in it. As a result, out of 2,204 patients infected with coronavirus, 1,454 or 66 percent of patients have fully recovered. 83 percent of quarantined people have already returned home. Positive dynamics are evident. All necessary measures are being taken to treat 740 patients remaining in hospitals, restore their health and return them to their families. All this is not easy. On May 5, 2020, we sent 2trillion 250billion soum from the Anti-Crisis Fund and \$500 million from the funds of international financial institutions. Today, no one in the world knows how long a pandemic will last. Therefore, no matter how difficult it may be, we must learn to work and live in a pandemic, in accordance with all requirements. ${ }^{5,6}$

Now, taking advantage of the fact that the epidemiological situation has changed for the better, we must gradually weaken the quarantine regime in our economy. These restrictions have a huge negative impact on economic development and the life of the population. In this regard, we have taken the first steps to soften the quarantine requirements in order to create convenience for our people, especially farmers and entrepreneurs.

This year, all of humanity is testing for strength, including Uzbekistan. In the past week alone, the people of Uzbekistan have faced a series of unexpected trials. Everyone is well aware of the severe natural disaster that occurred on the night of April 28 in the Bukhara region, especially in the Alat and Karakul regions. It damaged more than 38,000 homes, as well as 847 social facilities and crops throughout the region. Serious damage has been done to agriculture, manufacturing, services and infrastructure.

The government of the country took all necessary measures to eliminate the consequences of the elements. The government commission worked around the clock. On May 2020, the roofs of 70 percent of social facilities and 20 percent of the homes were restored. In addition, 5 thousand kilometres of power lines, 1.1 thousand transformers were repaired and power supply was restored for 286 thousand residents. Individual houses are also being repaired. Unfortunately, the tests did not end there. As everyone knows, due to the emergency at the Sardoba reservoir in the Syrdarya region, about 90 thousand people from 24 makhallas of the Sardoba, Akaltyn and Mirzaabad districts were immediately evacuated to safe areas. All of them are provided with basic necessities, food, clothing and other products. The government commission worked to eliminate the consequences and investigate the causes of the flood. Until all issues related to the restoration and repair of damaged housing, the return of people to their homes, the provision of assistance in establishing a home, the restoration of infrastructure, and the protection of public health are resolved, all managers assigned to the Syrdarya worked under heavy duty.

The life of people in these areas was restored to their previous state, but also improved. The President of the Republic of Uzbekistan Shavkat Mirziyoyev said that we are obliged to build new housing, social facilities, create new jobs. To date, a number of makhallas have carried out large-scale work to clear and restore, as a result of which more than 53thousand people have returned to their homes or moved to the homes of close relatives. Ours is determined that the state and society will not leave anyone unattended in the face of such unexpected disasters. The Ministry of Emergency Situations, the Ministry of the Interior and the Ministry of Defense, as well as the National Guard played an important role in saving lives and evacuating people. They are widely involved in disaster recovery. Unfortunately, according to available data, 4 people died as a result of a natural disaster, 1 went missing. In particular, two officers of the National Guard were carried away by a strong stream of water during the warning and rescue operations. They sacrificed their lives and saved the lives of hundreds, thousands of people. President of 
the country Shavkat Mirziyoyev expressed his deepest condolences to the families and friends of the victims. The courage of our guys will become for all their colleagues and young people a model of devotion, selfless service to the Motherland and our people, the president said. he further noted that, of course, the disasters in Bukhara and the Syrdarya are a test sent to us by the Almighty. We must survive it steadily, working hard.

I want to emphasize that despite these difficulties, our people were not confused in the face of trials. You can see on TV how our people are becoming more united, every day, every minute they show kindness, tolerance, great generosity. This is also evidenced by the fact that residents of the Syrdarya, Jizzakh and Tashkent regions voluntarily sheltered 81 percent of those evacuated from Sardoba, Akaltyn, Mirzaabad districts. Other regions, ministries, companies and associations, as well as compatriots, for a short time gathered a lot of help for Bukhara and Syrdarya, sent building materials, food, clothes, medicines and household products. The President of the Republic of Uzbekistan noted that taking this opportunity, I want to once again express my sincere gratitude to our generous, generous and compassionate people. Our people can be calm, there should be no place for any speculation and rumors. At my request, the law enforcement authorities launched an objective, impartial and comprehensive investigation into the flood incident. I assure you that all those guilty, regardless of who they are and what position they hold, will answer before the law, the president said.

This flood was a bitter lesson for us. With the involvement of international experts, we will conduct a deep examination of the entire dam. Only then will we come to a final conclusion, said Shavkat Mirziyoyev. Then noted that, in addition, on my behalf, all relevant hydropower facilities, dams and hydroelectric power plants, which may be subject to erosion due to heavy rains, are currently being checked by the relevant state authorities.

Unfortunately, as a result of the disaster in Sardoba, some settlements in the neighbouring Maktaaral district of the Turkestan region of the Republic of Kazakhstan were also flooded. We with the President of Kazakhstan, respected Kassym-Zhomart Tokaev, in the spirit of mutual understanding and openness, discussed this issue during a telephone conversation. Yesterday, a delegation led by Akim of Turkestan region Umirzak Shukeyev visited the scene and studied the situation in detail. For a long time, we have lived with the fraternal Kazakh people side by side, we drank water from the same river, we are close as relatives. We always stood shoulder to shoulder and supported each other, both on bright days and during test periods. We are very sorry that this unexpected technological disaster caused so many troubles and caused damage not only to our population, but also to our neighbours, our brothers, whose settlements and crops were also damaged. Our government, relevant ministries and departments, local khokimiyats, other responsible persons and experts, as well as Kazakhstani partners, of course, will closely cooperate in combating the consequences of the disaster. We also expressed our readiness to provide our Kazakhstani brothers with the necessary assistance in the aftermath of the disaster. I am convinced that together with our people we will overcome these difficulties together and amicably, said the President of the Republic of Uzbekistan Shavkat Mirziyoyev. Therefore, it is necessary to carefully bring expertise in all Central Asian countries with a dam.

In recent years, the country has been consistently implementing reforms in the field of water use, including water supply and sanitation, with the adoption of comprehensive measures for the rational use of water, ensuring its quality and safety, as well as the introduction of modern innovative water metering systems. New water management structures have been created to ensure effective regulation of water use, work is actively being carried out to attract the private sector in the field of water supply and sanitation. However, due to global climatic changes in the republic, the duration of dry seasons increases, the area of snow reserves in the mountains decreases, the frequency of low water increases, which leads to an increased risk of water shortages.

Along with this, coordination of the activities of authorized state bodies in managing the country's water balance is not carried out at the proper level, and an effective system for monitoring the quality and safety of water resources has not been established.

In order to ensure the rational use of water, to meet the needs of the population and sectors of the economy for safe and high-quality water resources, to create an effective water balance management system, and also in accordance with the objectives of the Strategy of Action for the five priority areas of development of the Republic of Uzbekistan in 2017-2021:

The President of the Republic of Uzbekistan adopted the Decree "On measures to improve the management of water resources of the Republic of Uzbekistan to increase the level of drinking water supply and improve its quality" dated November 26, 2019.

The decree noted that the Ministry of Housing and Public Utilities of the Republic of Uzbekistan, with the assistance of leading foreign experts, is developing a concept for the Development Strategy for water supply and sanitation of the Republic of Uzbekistan, which provides for:

a. The creation of a unified centralized system for recording, monitoring, ensuring the safety and quality of water of the Unified State Water Fund of the republic, as well as the formation of a single water balance;

b. The organization on the basis of water supply enterprises of the republic of a separate corporate structure that performs the function of a single operator in the operation of water supply and sanitation facilities;

c. Implementation of the Digital water canal system, which provides automation of the republic's water management system and digitalization of all business processes in this field;

d. Attracting investments, including on public-private partnership, with the aim of modernizing and re-equipping the enterprises of the industry;

e. Cardinal improvement of the system of training, retraining and advanced training of industry specialists, taking into account modern requirements and standards.

The document determines that the Ministry is the authorized state body in the field of coordination of accounting, monitoring, safety and quality of water of the Unified State Water Fund, as well as the formation of a unified water balance, entrusting it with the following additional tasks:

Organization of the formation of a single water balance of the republic by collecting, summarizing and systematizing the information of authorized bodies and organizations on the quantitative and qualitative indicators of the waters of the Unified State Water Fund with the creation of a unified information system of the water balance; 
I. Monitoring the reliability of information provided by authorized bodies and organizations on the state of water metering, ensuring its safety and quality, with developing, if necessary, measures to eliminate identified shortcomings;

II. Coordination of the activities of authorized bodies and organizations for accounting, monitoring, ensuring the safety and quality of water of the unified state water fund;

III. Organization of the creation of strategic reserves of fresh drinking water, including the construction of large-capacity reserve sources;

IV. Coordination of the introduction of modern innovative technologies in the water use sector, including an automated system for accounting for the quantity and quality of water, ensuring their integration into a single information system for the water balance of the republic.

This decree instructs that the post of the first deputy minister responsible for organizing and coordinating the accounting, monitoring, ensuring the safety and quality of water of the Unified State Water Fund, the formation of a unified water balance of the republic, as well as the introduction of modern technologies in water supply systems be introduced into the structure of the central apparatus of the Ministry and water disposal.

a. The document instructed to create in the structure of the central apparatus of the Ministry:

b. General Directorate for the Formation and Monitoring of the Single Water Balance;

c. Management of safety and quality of water of the Unified State Water Fund;

d. Management of the introduction of modern technologies in water supply and sanitation.

It was entrusted to determine that the staffing level of the newly created departments of the Ministry is formed by reducing the corresponding number of staff units of the central apparatus and territorial divisions of the Ministry.

The decree instructed to agree with the proposals of the Ministry of Economy and Industry, the Ministry of Finance, the Agency for State Assets Management of the Republic of Uzbekistan on:

a. Transfer to the structure of the Ministry of the State Inspectorate for the Control of Use of Drinking Water under the Cabinet of Ministers of the Republic of Uzbekistan with its transformation into the Inspectorate for Control of Use of Drinking Water under the Ministry of Housing and Public Utilities of the Republic of Uzbekistan and the preservation of existing tasks and functions, as well as the procedure for financing;

b. The creation of the Uzsuvtaminot joint-stock company and the formation of its authorized capital by transferring assets and state shares in the authorized capital of the state unitary enterprises of the Ministry specified in the appendix to this Decree, as well as the transformation of these enterprises into limited liability companies;

c. The transfer from January 1, 2020 of the function of the Compulsory Enforcement Bureau under the General Prosecutor's Office of the Republic of Uzbekistan to ensure the completeness and timeliness of payments, to reduce consumer debt for the provided water supply and sanitation services of Uzsuvtaminot JSC and its member organizations.

\section{The document establishes the procedure in accordance with which:}

a. The Ministry maintains a unified information system for the water balance of the republic, reflecting data on quantitative and qualitative indicators for all types of water of the Unified State Water Fund;

b. The Ministry of Water Resources, the State Committee for Geology and Mineral Resources, the State Committee for Ecology and Environmental Protection, the State Committee for Land Resources, Geodesy, Cartography and the State Cadastre, the State Committee for Industrial Safety and the Center for Hydrometeorological Service under the Cabinet of Ministers of the Republic of Uzbekistan on a systematic basis submit to the Ministry accounting information on quantitative and qualitative indicators in relation to all types of waters of the Unified State Water Fund;

c. The Ministry monitors the accuracy of water metering, the state of its safety and quality with the inclusion of confirmed and updated information in a single database, and also works out measures to eliminate the identified deficiencies with a referral to authorized bodies and organizations in the field of regulation of water use;

The Ministry systematically submits to the Administration of the President of the Republic of Uzbekistan and the Cabinet of Ministers a report on the state of water accounting, ensuring its safety and quality, as well as the formation of a single water balance of the republic with specific proposals. The decree instructed the Cabinet of Ministers of the Republic of Uzbekistan to approve within two months the Regulation on the Inspectorate for Monitoring the Use of Drinking Water under the Ministry of Housing and Public Utilities of the Republic of Uzbekistan and the Road Map for further improvement of the system of providing the population of the republic with water supply and sanitation services.

The document instructed the Ministry of Finance, together with the Ministry, to take an inventory of the debts of water supply enterprises to international financial institutions within a month and submit proposals to the Cabinet of Ministers on its repayment with a decrease in the financial burden on the State budget of the Republic of Uzbekistan. The Ministry of Investment and Foreign Trade of the Republic of Uzbekistan, together with the Ministry, was instructed to ensure the formation of a list of projects for the coming years to improve water supply and sanitation systems implemented at the expense of credit funds of international financial institutions, as well as the development of feasibility studies for them to prevent the implementation of low-profitable projects within a month projects and projects for which credit coverage from services provided is less than 50percent. It was entrusted to the Ministry together with the Ministry of Investments and Foreign Trade, the Agency for the Development of Public-Private Partnership under the Ministry of Finance of the Republic of Uzbekistan, the Council of Ministers of the Republic of Karakalpakstan and the khokimiyats of the regions within a month to take measures to implement projects on the terms of a public-private partnership for the modernization and management of water supply systems and water disposal of the Republic of Karakalpakstan and regions with the involvement of foreign consultants. 
It was entrusted to the National Agency for Project Management under the President of the Republic of Uzbekistan, the Ministry for the Development of Information Technologies and Communications, together with other interested departments, within three months to ensure the development of strategic directions, a unified approach, mechanisms and stages of automation and digitalization of all water use processes. It is entrusted to make additions and changes to some acts of the President of the Republic of Uzbekistan according to the appendix.

It is also entrusted to the Ministry, together with the concerned departments, within one month to submit to the Cabinet of Ministers:

a. Draft resolution of the President of the Republic of Uzbekistan on further improvement of the water supply system of the republic;

b. Proposals for amendments and additions to the legislation arising from this Decree.

\section{Acknowledgments}

None.

\section{Conflicts of interest}

Authors declare no conflict of interest exists.

\section{Funding}

None.

\section{References}

1. Economic Review of the Republic of Uzbekistan. 2017 - 2019.

2. Pravda Vostoka. 2017-2019.

3. People's Words. 2017-2019.

4. Kazakhstanskaya Pravda. 2017-2019.

5. Abdurahmonov K Kh, Dodoboev YT. Regional economies of Central Asia. Toshkent. 2006;450 p.

6. Decree of the President of the Republic of Uzbekistan. On measures to improve the management of water resources of the Republic of Uzbekistan to increase the level of provision of the population with drinking water and improve its quality. 2019. 